OF

\title{
THE DEPARTMENT OF AGRICULTURE
}

OF

\section{PORTO RICO}

Vol. II "JANHARY, I9I8 No./

\section{EXPERIMENTAL WORK ON THE CONTROL OF THE WHITE GRUBS OF PORTO RICO.}

By R. T. Cootron, Entomologist, Insular Experiment Station.

The white grubs of Porto Rico are known to have been present and dang damage on the Island for the last twenty-five years. How serious their ravages were previously we do not know, but since that time hey have become gradually more and more destructive, until at prisent it is impossible to grow ratoon cane in some sections of the Isand.

During the year of 1908 the sugar cane in the district of Guánica Central began to suffer very noticeably from the attack of the whis, grubs, and the following year, matters becoming still worse, stremous measures were started for discovering methods of contro.ing this serious pest.

From that time until the present, numerous and varied experimets have been conducted by various entomological workers of th Insular Experiment Station of Río Piedras and the Federal Eperiment Station, both independently, and in co-operation with th: management of Guánica Central and other centrals of the Island.

No report has ever been published on the results of the vast amount c: experimental work conducted along these lines, and although the lajority of the results are of a negative nature, they are of coniderable interest and some value to entomological workers. Thereore the writer has prepared this brief review.

A considerable portion of the work was carried out by the late Mr. C. T. Murphy, in charge of the experimental work at Guánica, in co-operation with $\mathrm{Mr}$. W. V. Tower, formerly entomologist of the Federal Experiment Station at Mayagïez, and Mr. D. L. Van Dine, former entomologist of the Experiment Station of the Sugar Producers' Association of Porto Rico. Portions of the work have also been conducted by Messrs. Thos. H. Jones and G. N. Wolcott, 


\section{CONTENTS.}

No. 1.-JANUARY.

Experimental Work on the Control of the White

Page.

Grubs of Porto Rico

R. T. COTTON

1

The Green Muscardine Fungus in Porto Rico Joen A. STEVENSON_-_ 19

Studies in Inheritance in Sugar CaneH. B. CowgILL___... 3

No. 2.-APRII.

Citrus Diseases of Porto Rico John A. Stevenson---

No. 3.-JULY.

A Check List of Porto Rican Fungi and a Host

Index JoHn A. STEVENSON_--

No. 4.-OCTOBER.

Inects attacking vegetables in Porto Rico R. T. COTTON 
former entomologists of the Insular Experiment Station, and by former assistant entomologist Eugene G. Smyth. Mr. R. H. Van Zwaluwenburg, entomologist of the Federal Experiment Station at Mayagïez, has also carried out work along this line, as is noted hereafter. Credit is due to all of these workers for the data given below.

Mr. Eugene G. Smyth, who has recently published an article ${ }^{1}$ on the white grubs injuring sugar eane in Porto Rico, states that ten distinct species of white grubs have been segregated ard studied. Of these, four belong to the genus Phyllophaga and one to the genus Phytalus in the tribe Melolonthini, while the other five velong to three genera in the tribe Dynastini.

It was in connection with the members of the genus Phylophaga that most of the experimental work was conducted and to which the following data apply.

The various experiments have been grouped according to he following headings: soil fumigants, soil insecticides, mechanical methods, poison sprays, and parasitic insects and diseases. Spac does not permit the publication of all the experiments conducted ir some cases, so selections have been taken that represent the typical results obtained in each group.

\section{SOIL FUMIGANTS.}

Under this heading have been grouped the experiments condicted with carbon bisulphide, gasoline, tobaceo extract, potassium cyaride, and vaporite, since in all cases the gases or fumes given off by tiese substanees were depended upon to kill the grubs.

\section{Carbon bisulphide.}

To test the value of carbon bisulphide as a killing agent, to tetermine the best method of application, and the most efficient amout of the liquid to use, the two following experiments were made. They were conducted in cane land severely infested with grubs:

Experiment 1.-Use of Carbon Bisulphide in Killing the White Grub.

\begin{tabular}{|c|c|c|c|c|c|c|c|c|}
\hline \multirow{2}{*}{$\begin{array}{c}\text { No. } \\
\text { of } \\
\text { plot }\end{array}$} & \multirow{2}{*}{$\begin{array}{l}\text { No. } \\
\text { of stools } \\
\text { of cane }\end{array}$} & \multirow{2}{*}{$\begin{array}{l}\text { Amount } \\
\text { CS } 2 \\
\text { applied }\end{array}$} & \multirow{2}{*}{$\begin{array}{l}\text { How } \\
\text { applied }\end{array}$} & \multirow{2}{*}{$\begin{array}{c}\text { When } \\
\text { examined }\end{array}$} & \multirow{2}{*}{$\begin{array}{l}\text { Average } \\
\text { No. } \\
\text { grubs } \\
\text { per stool }\end{array}$} & \multicolumn{2}{|c|}{$\begin{array}{l}\text { No. of grubs after } \\
\text { treatment }\end{array}$} & \multirow{2}{*}{$\begin{array}{c}\text { Per cent } \\
\text { of grubs } \\
\text { killed }\end{array}$} \\
\hline & & & & & & Alive & Dead & \\
\hline 1 & 4 & $25 \mathrm{ce}$. & $\begin{array}{l}\text { Hole in cen- } \\
\text { ter of stool. }\end{array}$ & 48 hours later & 8 & 11 & 21 & 65 \\
\hline-2 & 4 & $50 \mathrm{ec}$ & & 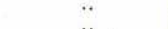 & 16 & 5 & 60 & 92 \\
\hline$: 3$ & 4 & & $\begin{array}{l}\text { In } 2 \text { holes at } \\
\text { side of stool }\end{array}$ & .. & & & & 14 \\
\hline 4 & + & 500 & & .. & 1 & 3 & 6 & 14 \\
\hline 5 & 4 & $25 \mathrm{ce}$. & $\begin{array}{l}\text { In } 1 \text { hole at } \\
\text { side of stool }\end{array}$ & " & 17 & 52 & 15 & 24. \\
\hline 6 & 3 & $50 \mathrm{ec}$. & & . $\cdot \cdot$ & 6 & 25 & 1 & 4 \\
\hline
\end{tabular}

1 Journal of the Dept. of $A$ grie. of P. R., Vol. 1, no. 2., pp. 47-92, no. 3, pp. 141-69. 
Experiment II.-Use of Carbon Bisulphide in Killing White Grubs.

\begin{tabular}{|c|c|c|c|c|c|c|}
\hline $\begin{array}{l}\text { No. } \\
\text { of } \\
\text { plot }\end{array}$ & $\begin{array}{l}\text { No of } \\
\text { stools of } \\
\text { eane }\end{array}$ & $\begin{array}{l}\text { Amount } \\
\text { CS2 } \\
\text { applied }\end{array}$ & How applied & $\begin{array}{l}\text { Depth of } \\
\text { injection }\end{array}$ & $\begin{array}{c}\text { When } \\
\text { examined }\end{array}$ & $\begin{array}{l}\text { Per cent } \\
\text { of grubs } \\
\text { killed }\end{array}$ \\
\hline $\begin{array}{r}1 \\
2 \\
3 \\
4 \\
5 \\
+6 \\
-7\end{array}$ & 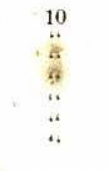 & $\begin{array}{c}12.5 \mathrm{cc} . \\
25 \text { ce. } \\
50 \text { ce. } \\
25 \text { ce. } \\
50 \text { ce. } \\
\ldots \\
\ldots\end{array}$ & 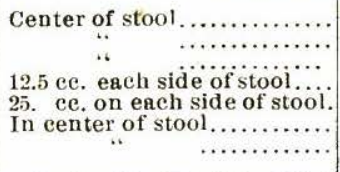 & $\begin{array}{c}5 \text { inches.. } \\
. . \\
. . \\
. \\
3 \text { inches.. } \\
. .\end{array}$ & $\begin{array}{c}5 \text { days later } \\
. . \\
.6 \\
.: \\
: . \\
.:\end{array}$ & $\begin{array}{l}60 \\
65 \\
75 \\
78 \\
76 \\
90 \\
66\end{array}$ \\
\hline
\end{tabular}

As a result of these experiments it was seen that carbon bisulphide was a good killing agent, and that the best results were obtained by putting the charge in the center of the stools of cane at a depth of about three inches. It was also noted, however, that severe injury resulted to the cane plants from the carbon bisulphide when amounts greater than 12.5 ec. were used.

An experiment was then conducted at Guánica Central, under the direct supervision of Mr. C. T. Murphy, to test out the value of earbon bisulphide on a field scale. Some thirty-three odd acres of land planted to sugar eane were used, arranged in five different sections of $3,3,4,6$, and 4 plots, respectively. One check plot was left in each section.

The carbon bisulphide was injected by the use of several "Pal Injecteurs" imported from Germany at a cost of $\$ 31.57$ each. They were so arranged that any amount of liquid desired could be injected at one time. The only drawback in the use of these instruments was the action of the earbon bisulphide on the rubber connections and leather washers. These very quickly disintegrated, and the small pieces of rubber and leather clogged up the holes through which the liquid was forced. Specially devised rubber eonnections finally overcame this difficulty, however.

Carbon bisulphide was found to be a most disagreeable and dangerous liquid to handle, for although no serious aceidents happened, numerous burns about the hands and face were experienced by the men who applied it.

In all, eight thousand eight hundred pounds of this material were used in the experiment at a cost of six cents a pound. The cost of application was $\$ 67.05$. The cost of material and labor for the application of fifteen grams per stool of cane amounted to $\$ 15.53$ per acre; for the application of thirty grams per stool, $\$ 31.06$ per acre. The following tables give the results of the experiment: 


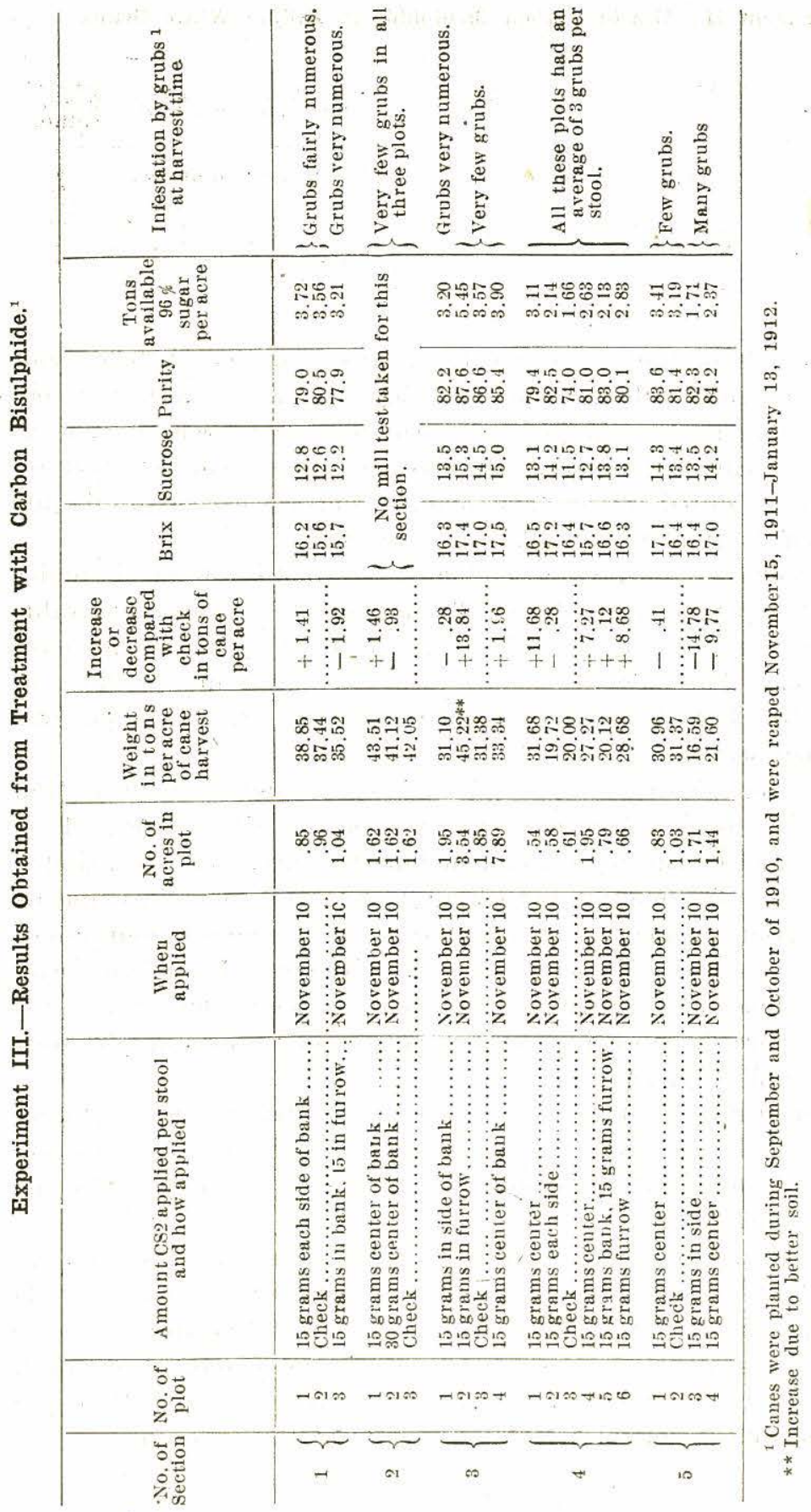


All plots in this experiment received the same cultural treatment. The only factor that could not be controlled was the condition of the soil. In section four the check plot unfortunately fell upon a piece of bad soil which reduced the yield at least ten tons below the average normal crop per acre. If we disregard this plot, we then find that on six of the ten treated plots the yield fell below the check plots. In all cases where a double dose was applied the yield was lower than on the check plot. The carbon bisulphide had a detrimental effect on the growth of the cane plants.

Altogether the results do not warrant a further use of carbon bisulphide as a means of control for the white grubs in growing cane, for although it may kill the grubs in the stool when first applied the effect is not lasting, and as the egg-laying season of the beetle extends over a rather long period the land soon becomes reinfected and at least three applications a season would be necessary to keep the land free from the grubs. The expense of the material would in any case render such an operation prohibitive. The liquid is dangerous and disagreeable to handle, and furthermore it is injurious to the cane, stunting its growth and often killing the plant.

\section{Carbon bisulphide and gasoline.}

In an endeavor to find a mixture that would be cheaper and less injurious to plant life than carbon bisulphide, experiments were tried with gasoline and various mixtures of gasoline and carbon bisulphide. The following table shows the results obtained:

\section{Experiment IV.-Use of Carbon Bisulphide and Gasoline Against White Grubs.}

\begin{tabular}{|c|c|c|c|c|c|c|c|}
\hline \multirow{2}{*}{$\begin{array}{l}\text { No. } \\
\text { of } \\
\text { plot }\end{array}$} & \multirow{2}{*}{$\begin{array}{c}\text { No. } \\
\text { of stools } \\
\text { of cane }\end{array}$} & \multirow{2}{*}{ Liquid used } & \multirow{2}{*}{$\begin{array}{l}\text { Amount } \\
\text { per stool }\end{array}$} & \multirow{2}{*}{$\begin{array}{c}\text { Where } \\
\text { applied in } \\
\text { stool }\end{array}$} & \multicolumn{2}{|c|}{$\begin{array}{l}\text { Grubs found after } \\
\text { treatment }\end{array}$} & \multirow{2}{*}{$\begin{array}{c}\text { Per cent } \\
\text { grubs } \\
\text { killed }\end{array}$} \\
\hline & & & & & Alive & Dead & \\
\hline $\begin{array}{l}1 \\
2 \\
9 \\
3 \\
4 \\
5 \\
6 \\
6 \\
7 \\
8\end{array}$ & $\begin{array}{r}10 \\
10 \\
10 \\
\\
5 \\
5 \\
5 \\
10 \\
\\
3 \\
5\end{array}$ & 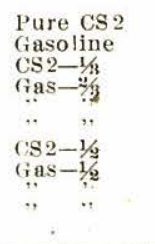 & $\begin{array}{ll}20 & \text { grams } \\
20 & \text { g.. } \\
& \\
& \\
10 & . . \\
40 & . \\
& \\
20 & . . \\
10 & . . \\
40 & . .\end{array}$ & $\begin{array}{c}\text { Center } \\
. . \\
. . \\
. \\
., \\
. . \\
.\end{array}$ & $\begin{array}{r}6 \\
20 \\
10 \\
\\
31 \\
2 \\
18 \\
9 \\
6\end{array}$ & $\begin{array}{r}150 \\
147 \\
179 \\
\\
57 \\
59 \\
\\
127 \\
18 \\
66\end{array}$ & $\begin{array}{l}96 \\
93 \\
95 \\
\\
\\
65 \\
97 \\
\\
87 \\
66 \\
91\end{array}$ \\
\hline
\end{tabular}

All experiments conducted with these two liquids consistently showed that they had almost equal killing powers and could be mixed as desired. However, when applied to young cane all the mixtures 
in quantities of twenty grams or more severely burned the plants, and even with mature cane severe injury resulted.

Hence it was found impossible to use gasoline as a substitute or as an adulterant for carbon bisulphide. The great increase in the cost of gasoline at the present time would of course preclude its use, even had it proved to be non-injurious to plant life.

Potassium cyanide.

In view of the deadly nature of potassium cyanide and of, reports of its successful use in controlling certain forms of subterranean insects, it seemed desirable to try it out against the white grubs. Experiments were accordingly carried out in which potassium cyanide in both liquid and crystal form was applied in various amounts and at varying depths in the soil, around the roots of the suyar cane.

The potassium-cyanide solution was prepared by dissolving two hundred grams of the crystals in a liter of water. Five grams of the crystals were thus equivalent to twenty-five ce. of solution. For purposes of comparison equivalent amounts of potassium cyanide were used in both experiments. The following tables show the results obtained:

Experiment V.-Experiment with Potassium Cyanide in Liquid Form.

\begin{tabular}{|c|c|c|c|c|c|c|c|c|}
\hline \multirow{2}{*}{$\begin{array}{l}\text { PIot } \\
\text { No. }\end{array}$} & \multirow{2}{*}{$\begin{array}{c}\text { No. } \\
\text { of stools } \\
\text { of cane }\end{array}$} & \multirow{2}{*}{$\begin{array}{l}\text { Amount } \\
\text { applied }\end{array}$} & \multirow{2}{*}{ How applied } & \multirow{2}{*}{$\begin{array}{l}\text { Depth } \\
\text { applied }\end{array}$} & \multirow{2}{*}{$\begin{array}{l}\text { When } \\
\text { applied }\end{array}$} & \multirow{2}{*}{$\begin{array}{c}\text { When } \\
\text { examined }\end{array}$} & \multicolumn{2}{|c|}{ No. grubs found } \\
\hline & & & & & & & Alive & Dead \\
\hline $\begin{array}{l}1 \\
2 \\
3 \\
4\end{array}$ & $\begin{array}{l}8 \\
8 \\
7 \\
7\end{array}$ & $\begin{array}{l}25 \mathrm{cc} . \\
", ", \\
50 \% \\
", .,\end{array}$ & $\begin{array}{c}\text { Center of stool } \\
., \\
. .\end{array}$ & $\begin{array}{l}3 \text { inches } \\
5 \\
3 \\
5\end{array}$ & $\begin{array}{cc}\text { Feb. } & 21 \\
, ", \\
, . & , " \\
", & , "\end{array}$ & $\begin{array}{cc}\text { March } & 3 \\
\ddot{*} & . . \\
, " & . .\end{array}$ & $\begin{array}{l}84 \\
87 \\
39 \\
74\end{array}$ & $\begin{array}{r}13 \\
7 \\
25 \\
16\end{array}$ \\
\hline
\end{tabular}

Experiment VI.-Experiment with Potassium Cyanide in Crystal Form.

\begin{tabular}{|c|c|c|c|c|c|c|c|c|}
\hline \multirow{2}{*}{$\begin{array}{l}\text { Plot } \\
\text { No. }\end{array}$} & \multirow{2}{*}{$\begin{array}{c}\text { No. } \\
\text { of stools } \\
\text { of cane }\end{array}$} & \multirow{2}{*}{$\begin{array}{l}\text { Amount } \\
\text { applied }\end{array}$} & \multirow{2}{*}{ How applied } & \multirow{2}{*}{$\begin{array}{l}\text { Depth } \\
\text { applied }\end{array}$} & \multirow{2}{*}{$\begin{array}{l}\text { When } \\
\text { applied }\end{array}$} & \multirow{2}{*}{$\begin{array}{c}\text { When } \\
\text { examined } \\
.\end{array}$} & \multicolumn{2}{|c|}{ No. grubs found } \\
\hline & & & & & & & Alive & Dead \\
\hline $\begin{array}{l}1 \\
2 \\
3 \\
4 \\
5 \\
5 \\
6 \\
7 \\
8\end{array}$ & $\begin{array}{l}1 \\
1 \\
2 \\
5 \\
4 \\
4 \\
5 \\
5\end{array}$ & 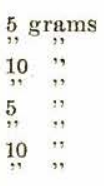 & $\begin{array}{c}\text { Center of stool } \\
, ", \\
., \\
., \\
.,\end{array}$ & $\begin{array}{ll}5 & \text { inches } \\
3 & , \\
5 & . \\
3 & . \\
5 & , \\
3 & , . \\
5 & . \\
3 & " .\end{array}$ & $\begin{array}{cc}\text { Feb. } & 21 \\
,, & , " \\
, & , " \\
, & , " \\
, & , " \\
, & ,\end{array}$ & 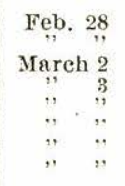 & $\begin{array}{r}11 \\
27 \\
26 \\
45 \\
64 \\
68 \\
78 \\
111\end{array}$ & $\begin{array}{r}2 \\
0 \\
8 \\
18 \\
2 \\
26 \\
5 \\
12\end{array}$ \\
\hline
\end{tabular}

From the above tables we see that there was very little difference 
in favor of either form of the cyanide as a killing agent. In all cases the injection at three inches gave better results than at five inches. However, neither form of potassium cyanide gave results that would warrant its use as a soil fumigant in controlling the white grub.

The experiments tend to show that the poison has but small powers of penetration when applied in such a manner. The danger incident upon the application of such a powerful poison under existing labor conditions, would in any case render the advisability of using this substance very doubtful.

\section{Tobacco.}

Tobacco is an old-time remedy for insect pests, and although it is only effective when used against delicate soft-bodied insects, frequent attempts were made to control the white grubs with it. The following experiment indicates the average results obtained with this substance. Tobaceo water was made by stecping eight ounces of eured tobacco in three gallons of water. It was then applied in pint doses to holes in the soil around the cane stools.

Experiment VII.-Experiment with Tobacco Water Against the White Grub.

\begin{tabular}{|c|c|c|c|c|c|c|c|c|}
\hline \multirow{2}{*}{$\begin{array}{l}\text { No. } \\
\text { of } \\
\text { plot }\end{array}$} & \multirow{2}{*}{$\begin{array}{l}\text { No. of } \\
\text { strols of } \\
\text { cane }\end{array}$} & \multirow{2}{*}{$\begin{array}{l}\text { A mount } \\
\text { applied }\end{array}$} & \multirow{2}{*}{\multicolumn{2}{|c|}{ How applied }} & \multirow{2}{*}{$\begin{array}{l}\text { When } \\
\text { applied }\end{array}$} & \multirow{2}{*}{$\begin{array}{c}\text { When } \\
\text { examined }\end{array}$} & \multicolumn{2}{|c|}{ No. of grubs found } \\
\hline & & & & & & & Alive & Dead \\
\hline $\begin{array}{l}1 \\
2 \\
3 \\
4\end{array}$ & $\begin{array}{l}6 \\
6 \\
6 \\
6\end{array}$ & $\begin{array}{ll}1 & \text { pint } \\
1 & \because \\
1 & \because \\
1 & \cdots\end{array}$ & $\begin{array}{l}\text { Hole in center of stool } \\
\text { Hole each side of stool }\end{array}$ & $\begin{array}{l}\cdots \cdots \\
\cdots \\
\cdots \cdots\end{array}$ & $\begin{array}{c}\text { March } 28 \\
" \\
" \\
4\end{array}$ & $\begin{array}{c}\text { April } 2 \\
: . \\
\therefore \\
: .\end{array}$ & $\begin{array}{l}45 \\
33 \\
45 \\
42\end{array}$ & $\begin{array}{l}2 \\
3 \\
8 \\
5\end{array}$ \\
\hline
\end{tabular}

It is readily seen that the tobacco in this form had but very little effect on the white grubs. It is too weak in action and too expensive as well to apply in this manner.

Vaporite.

The last substance to be discussed under the heading of soil fumigants is vaporite, a commercial preparation put out in the form of a gray powder, which on coming into contact with moist soil gradually gives off a vapor. In accordance with directions for the most efficient method of using this material, it should be applied at some depth below the root system of the plant treated so that the vapor given off will kill the grubs and other insets infesting the roots as it rises to the surface. 
The following table shows the general trend of all the experiments conducted with this substance:

Experiment VIII.-Experiment with Vaporite Against the White Grubs.

\begin{tabular}{|c|c|c|c|c|c|c|c|c|}
\hline \multirow{2}{*}{$\begin{array}{c}\text { No. } \\
\text { of } \\
\text { plot }\end{array}$} & \multirow{2}{*}{$\begin{array}{l}\text { No. of } \\
\text { stools of } \\
\text { cane }\end{array}$} & \multirow{2}{*}{$\begin{array}{l}\text { Amount } \\
\text { applied } \\
\text { per } \\
\text { stool }\end{array}$} & \multirow{2}{*}{ How applied } & \multirow[t]{2}{*}{ · } & \multirow{2}{*}{$\begin{array}{l}\text { When } \\
\text { applied }\end{array}$} & \multirow{2}{*}{$\begin{array}{c}\text { When } \\
\text { examined }\end{array}$} & \multicolumn{2}{|c|}{ No. of grubs found } \\
\hline & & & & & & & Alive & Dead \\
\hline $\begin{array}{l}1 \\
2 \\
3 \\
4 \\
5\end{array}$ & $\begin{array}{l}2 \\
4 \\
6 \\
1 \\
1\end{array}$ & $\begin{array}{ll}4 & \mathrm{oz} . \\
2 & \mathrm{oz} . \\
1 & \mathrm{oz} . \\
2 & 0 \% . \\
2 & 0 \% .\end{array}$ & $\begin{array}{c}\text { Hole in center of stool } \\
. . \\
. \\
. \\
.\end{array}$ & $\begin{array}{l}\cdots \\
\cdots \\
\cdots \\
\cdots \\
\cdots\end{array}$ & $\begin{array}{l}\text { June } 8 \\
\text { May } 23\end{array}$ & $\begin{array}{c}\text { June } 14 \\
\ddot{6} \\
\text { May } 27\end{array}$ & $\begin{array}{r}6 \\
5 \\
17 \\
14 \\
20\end{array}$ & $\begin{array}{l}0 \\
0 \\
1 \\
0 \\
0\end{array}$ \\
\hline
\end{tabular}

The above results would tend to show that this substance had no effect whatever on the grubs. It is possible that the material had deteriorated somewhat before application.

\section{SOIL INSECTICIDES AND DETERRENTS.}

Under the heading of soil insecticides and deterrents have been grouped experiments with a large number of different chemicals and manurial agents in their relation to the control of the white grub. No special order has been observed in presenting them other than to arrange them as logically as possible.

Experiments with lime and various chemicals and chemical compounds mixed with lime.

Experiment IX.-Experiment with Ammoniac ${ }^{1}$ and Lime Against the White Grub.

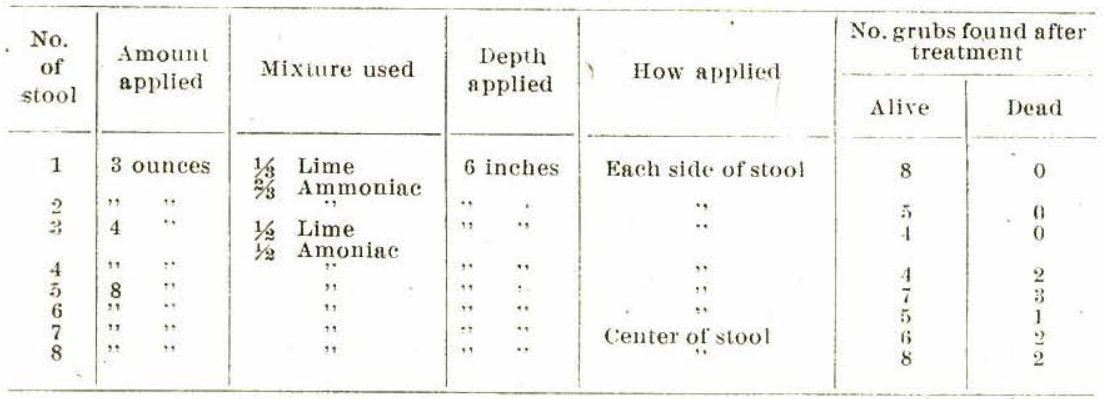

${ }^{1}$ Sal ammoniac (ammonium chloride).

As may be seen by the above table, the ammoniac and lime has little or no effect on the white grubs. 


\section{Experiment X.-Experiment with Carbolineum and Lime Against the White} Grub.

\begin{tabular}{|c|c|c|c|c|c|c|c|}
\hline \multirow{2}{*}{$\begin{array}{c}\text { No. } \\
\text { of } \\
\text { plot }\end{array}$} & \multirow{2}{*}{$\begin{array}{l}\text { No. of } \\
\text { stools } \\
\text { cane }\end{array}$} & \multicolumn{2}{|c|}{$\begin{array}{l}\text { Amount per stool } \\
\text { material used }\end{array}$} & \multirow{2}{*}{ How applied } & \multirow{2}{*}{$\begin{array}{c}\text { When } \\
\text { examined }\end{array}$} & \multicolumn{2}{|c|}{$\begin{array}{l}\text { No. of grubs found } \\
\text { after treatment }\end{array}$} \\
\hline & & Carbolineum & Lime & & & Alive & Dead $^{\prime}$ \\
\hline $\begin{array}{r}1 \\
2 \\
3 \\
4 \\
5 \\
6 \\
7 \\
8 \\
9 \\
10 \\
11 \\
12\end{array}$ & $\begin{array}{l}5 \\
5 \\
5 \\
5 \\
5 \\
5 \\
5 \\
5 \\
5 \\
5 \\
5 \\
5\end{array}$ & $\begin{array}{l}25 \mathrm{cc} . \\
50 \mathrm{cc} . \\
25 \mathrm{ce} . \\
50 \mathrm{ce} . \\
25 \mathrm{ce} . \\
50 \mathrm{ce} . \\
25 \mathrm{ce} . \\
25 \mathrm{ce} . \\
50 \mathrm{cc} . \\
100 \mathrm{ce} . \\
55 \mathrm{ce} . \\
50 \mathrm{ce} .\end{array}$ & 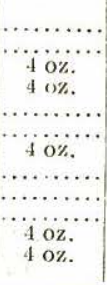 & 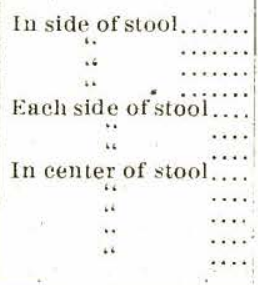 & 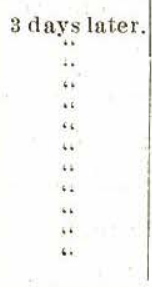 & $\begin{array}{r}27 \\
19 \\
18 \\
20 \\
21 \\
6 \\
2 \\
3 \\
21 \\
14 \\
10 \\
25\end{array}$ & $\begin{array}{l}2 \\
0 \\
0 \\
1 \\
1 \\
3 \\
0 \\
0 \\
0 \\
1 \\
0 \\
0\end{array}$ \\
\hline
\end{tabular}

The carbolineum, both alone and mixed with lime, had apparently no effect at all upon the grubs as a killing agent. Whether or not it had any value as a deterrent was determined in a field trial together with a number of other chemicals. The results are shown in the following table:

\section{Experiment XI.-Experiment with Lime and Combinations of Lime and Other Chemicals Against the White Grub.}

\begin{tabular}{|c|c|c|c|c|c|c|c|c|}
\hline $\begin{array}{l}\text { No. } \\
\text { of } \\
\text { plot }\end{array}$ & $\begin{array}{l}\text { Amount and kind of } \\
\text { materials used }\end{array}$ & $\begin{array}{c}\text { No. acres } \\
\text { treated }\end{array}$ & $\begin{array}{l}\text { Tons } \\
\text { yield } \\
\text { per } \\
\text { A }\end{array}$ & Brix & Sucrose & Purity & \begin{tabular}{|} 
Avail- \\
able tons \\
sigar \\
peracre
\end{tabular} & $\begin{array}{c}\text { No. } \\
\text { grubs } \\
\text { found } \\
\text { per stool }\end{array}$ \\
\hline 1 & $\begin{array}{l}\text { Kreso dip } 3 \text { gals. Live } \\
\text { lime } 300 \text { lbs. }\end{array}$ & .183 & 31.83 & 20.5 & 17.6 & 85.9 & 4.45 & 10 \\
\hline 2 & $\begin{array}{l}20 \% \text { carbolie acid } 5 \text { gals. } \\
\text { Lime } 500 \text { lbs. }\end{array}$ & .275 & 35.36 & 19.6 & 15.4 & 78.6 & 4.19 & 10 \\
\hline 3 & $\begin{array}{l}\text { Carbolineum } 5 \text { gals. } \\
\text { Lime } 500 \text { lbs. }\end{array}$ & .298 & 40.86 & 14.2 & 9.8 & 69.0 & 2.75 & 14 \\
\hline 4 & $\begin{array}{l}100 \text { carbolic acid } 5 \text { gals. } \\
\text { Lime } 500 \text { lbs. }\end{array}$ & .298 & 30.45 & 19.8 & 15.9 & 80.3 & 3.65 & 13 \\
\hline 5 & Live lime $250 \mathrm{lbs} . \ldots \ldots \ldots$ & .138 & 28.08 & 19.1 & 15.3 & 80.1 & 3.28 & 14 \\
\hline 6 & Cheek...... & .275 & 35.82 & 19.5 & 16.7 & 8.5. 6 & 4.54 & 15 \\
\hline
\end{tabular}

The sugar cane used in this experiment was planted in January, 1910, and reaped in April, 1911. The lime and other chemicals were applied May, 1910. As is shown by the table, none of the treated plots did so well as the eheck plot. Plot 3, although higher in yield per acre, was extraordinarily low in purity, but whether this was due to the treatment received or to some other factor, it is difficult to say.

The fact that more grubs were found per stool in the check plot would suggest that some of the chemicals applied exercised a slight deterrent power, but not sufficient to have any practical value. 


\section{Experiments with manurial agents.}

To test the value of various fertilizers or manurial agents as deterrents of the white grub an extensive series of experiments was conducted. At first, trials were made on a limited scale with beetles in confinement. Flower-pots containing soil and a small amount of fertilizer were placed in a cage with the beetles. Each pot had it different fertilizer mixed with the soil and the beetles had the opportunity to burrow in the pot that was most attractive to them. In this experiment advantage was taken of the habit of the beetles of hiding in the soil during the day. Examination was made of the pots each day and a count of the beetles in each made. Thus at the end of a week the total number of visits per pot was known and some* idea of the repellent or attractive powers of each material could be formed.

After a number of these preliminary trials, an experiment was conducted on a field scale with certain of the manurial agents, to determine their effect on the yield and quality of the cane, as well as their deterrent effect as exhibited over an entire growing season. The results are shown in the tabulations that follow.

In the first experiment nine pots of soil, each containing a smalI amount of fertilizer, were placed in a cage with fifty beetles. The following table gives the amount and kind of fertilizer in each pot, and the number of beetles that visited each pot daily for a week:

Experiment XII.-Repellant Effect of Various Manurial Agents on May Beetles.

\begin{tabular}{|c|c|c|c|c|c|c|c|c|c|c|}
\hline \multirow{2}{*}{$\begin{array}{c}\text { No. } \\
\text { of } \\
\text { pot }\end{array}$} & \multirow{2}{*}{ Manurial Agent } & \multirow{2}{*}{$\begin{array}{c}\text { Amount } \\
\text { used }\end{array}$} & \multicolumn{7}{|c|}{ Number of beetles found in pot on the } & \multirow{2}{*}{$\begin{array}{c}\text { Total } \\
\text { for } \\
\text { week }\end{array}$} \\
\hline & & & 1st. day & 2nd. & 3rd. & 4th. & 5 th. & 6th. & ith. & \\
\hline 1 & Ammonium Sulphate & 1 ounce & 6 & 2 & 3 & 9 & 9 & 12 & 17 & 48 \\
\hline 2 & Potassium Chloride.. & 1 & 2 & $\overline{3}$ & 1 & 0 & 0 & 2 & 2 & 10 \\
\hline 3 & Potassium Sulphate.. & ". & 4 & 5 & 4 & 5 & 1 & 0 & 4 & 23 \\
\hline 4 & Blood...$\ldots \ldots \ldots \ldots \ldots$ & $"$ & 9 & 12 & 11 & 3 & 7 & 21 & 17 & 80 \\
\hline 5 & Cyanamid $\ldots \ldots \ldots \ldots$ & , & 0 & 0 & 2 & 7 & 2 & 0 & 0 & 11 \\
\hline 6 & Lime & , & 0 & 0 & $\tilde{0}$ & 0 & 11 & 0 & 0 & 11 \\
\hline 7 & 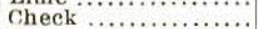 & " & 16 & 9 & 11 & 4 & 14 & 0 & 5 & 59 \\
\hline 8 & 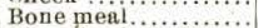 & ," & 9 & 7 & 13 & 13 & 2 & 5 & 4 & 53 \\
\hline 9 & Phosphoric Acid...... & 1. & 9 & 12 & 5 & 10 & $\overline{4}$ & 10 & 11 & 61 \\
\hline
\end{tabular}

In the experiment that follows the same materials were used and in the same proportions. However, in this case ten beetles were placed in each pot and at the end of a week the pots were examined and the living and dead beetles in each counted. Thus some indication of the killing power as well as the repellant action was given. 


\section{Experiment XIII.-Repellent and Killing Effect of Various Manurial Agents on May Beetles.}

\begin{tabular}{|c|c|c|c|c|c|}
\hline \multirow{2}{*}{$\begin{array}{l}\text { No. } \\
\text { of } \\
\text { pot }\end{array}$} & \multirow{2}{*}{ Manurial agemt } & \multirow{2}{*}{1} & \multirow{2}{*}{$\underset{\text { used }}{\text { Amount }}$} & \multicolumn{2}{|c|}{$\begin{array}{l}\text { Beetles found at enci } \\
\text { of week }\end{array}$} \\
\hline & & & & Dead & Alive \\
\hline $\begin{array}{l}1 \\
2 \\
3 \\
4 \\
5 \\
6 \\
7 \\
8 \\
9 \\
9\end{array}$ & 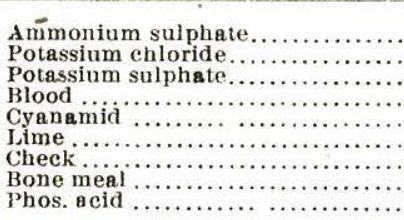 & 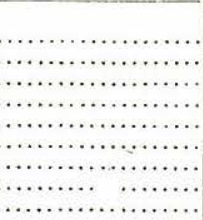 & 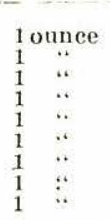 & $\begin{array}{r}1 \\
35 \\
3 \\
6 \\
3 \\
4 \\
0 \\
3 \\
10 \\
10\end{array}$ & $\begin{array}{r}2 \\
0 \\
0 \\
0 \\
0 \\
0 \\
12 \\
1 \\
1\end{array}$ \\
\hline
\end{tabular}

From the data given in the two preceding tables the following: facts are suggested:

Ammonium sulphate does not act as a repellent but shows good. killing powers.

Chloride of, potash acts as a good repellent.

Potassium sulphate and acid phosphate do not repel but have" some killing action.

Cyanamid and lime are good repellents, whereas blood and bone meal are very attractive to the beetles.

Whether or not these qualities hold up under field conditions may be seen in the data given under Experiment XV.

The following experiment was conducted in the same manner as Experiment XII, with the exception that different chemicals were: applied to the soil in the pots.

Experiment XIV.-Repellent Effect of Various Chemicals to May Beetles.

\begin{tabular}{|c|c|c|c|c|c|c|c|c|c|}
\hline \multirow{2}{*}{$\begin{array}{l}\text { No. } \\
\text { of } \\
\text { pot }\end{array}$} & \multirow{2}{*}{ Chemical added } & \multirow{2}{*}{$\underset{\text { used }}{\text { Amount }}$} & \multicolumn{6}{|c|}{ Number of beetles found in the pots on } & \multirow{2}{*}{ Total } \\
\hline & & & 1st day & $2 \mathrm{~d} d a y$ & $3 r d$ day & 4 th day & 5 th day & 6 th day & \\
\hline 1 & Lime 9 pts., sulphur 1 & 2 ounces & 0 & 12 & 6 & 2 & 0 & 3 & 23 \\
\hline 2 , & Carbolic acid $1 / 2 \% \ldots$ & $2 \quad \cdots$ & 0 & 11 & 8 & 19 & 0 & 1 & 39 \\
\hline 3 & $\begin{array}{l}\text { Boiled lime sulphur } \\
2-2-50\end{array}$ & 1 ounce & 0 & 0 & 6 & 8 & 1 & 8 & 23 \\
\hline t & $\begin{array}{l}\text { Self-boiled lime sul- } \\
\text { phur } 2-2-50\end{array}$ & $1 "$. & 0 & 7 & 6 & 2 & 9 & 3 & 27 \\
\hline 5 & $\begin{array}{l}\text { Caustic soda } 1 \text { lb., } \\
\text { su Ip hu r } 3 \text { lbs.. } \\
\text { water } 50 \text { gals. }\end{array}$ & 11 & 10 & 0 & 6 & 2 & 4 & 5 & $2 \%$ \\
\hline 6 & Filter-press cake..... & 2 ounces & 8 & 2 & 6 & 10 & 6 & 7 & 39 \\
\hline 7 & $\underset{1-8}{\text { Kerosene emulsion }}$ & $2 \quad \cdots$ & 20 & 16 & 6 & 7 & 4 & 6 & 59 \\
\hline 8 & Check......... & n.w. & 12 & 2 & 6 & 0 & 26 & 12 & 58 \\
\hline
\end{tabular}


With the exception of the kerosene emulsion, there was apparently very little difference in the repellent properties of those chemicals. None of them ean be considered as first-class repellents. An experiment with the same chemicals to test their killing powers gave such conflicting results that it has not been included in this report.

The following experiment was carried out to test the value of some of the fertilizers previously referred to, when used under field conditions. Plots of one hundred stools of cane were used tor each different fertilizer, and at the end of the season the effect on the yield and quality of the eane, and the number of white grubs was determined.

Experiment XV.-Manurial Agents as Deterrents for White Grub.

\begin{tabular}{|c|c|c|c|c|c|c|c|c|c|}
\hline $\begin{array}{c}\text { No. } \\
\text { of } \\
\text { plot }\end{array}$ & Manurial agent used & $\begin{array}{l}\text { Amount } \\
\text { per } \\
\text { stool } \\
\text { applied }\end{array}$ & $\begin{array}{l}\text { Yield in } \\
\text { tons } \\
\text { per acre }\end{array}$ & Brix & Suc. & Gluc. & Pur. & $\begin{array}{l}\text { Average } \\
96 \% \text { sugar } \\
\text { per acr. } \\
\text { in tons }\end{array}$ & $\begin{array}{l}\text { A rerage } \\
\text { No. } \\
\text { grubs } \\
\text { per stool }\end{array}$ \\
\hline $\begin{array}{r}1 \\
2 \\
3 \\
4 \\
5 \\
6 \\
7 \\
8 \\
9 \\
10\end{array}$ & 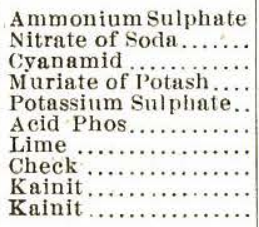 & 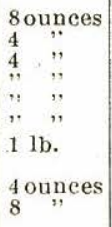 & $\begin{array}{l}22.57 \\
25.74 \\
22.97 \\
29.30 \\
25.74 \\
26.93 \\
28.12 \\
29.30\end{array}$ & $\begin{array}{l}19.4 \\
19.2 \\
20.1 \\
18.7 \\
19.7 \\
20.4 \\
20.2 \\
19.6 \\
21.0 \\
18.9\end{array}$ & $\begin{array}{l}15.3 \\
15.8 \\
15.4 \\
16.8 \\
16.7 \\
17.4 \\
17.3 \\
16.1 \\
18.4 \\
15.8\end{array}$ & $\begin{array}{l}2.50 \\
2.38 \\
2.38 \\
2.27 \\
2.17 \\
1.78 \\
2.08 \\
2.17 \\
1.92 \\
2.27\end{array}$ & $\begin{array}{l}79.0 \\
82.3 \\
76.6 \\
89.8 \\
84.8 \\
85.3 \\
81.7 \\
82.1 \\
87.6 \\
83.6\end{array}$ & $\begin{array}{l}3.15 \\
4.45 \\
2.55 \\
3.44 \\
2.98 \\
3.97 \\
3.48 \\
3.27 \\
4.08 \\
3.70\end{array}$ & $\begin{array}{r}11 \\
6 \\
1 \\
8 \\
10 \\
10 \\
14 \\
10 \\
7 \\
5\end{array}$ \\
\hline
\end{tabular}

From the data presented in the preceding table it is seen that of the materials used cyanamid alone maintained its repellent effect throughout the season. Its effect upon the yield, however, was not good, and the cost of such a treatment, without obtaining a fertilizing compensation to partly offset this cost would make such a practice prohibitive. Further experiments with cyanamid alone have moreover given but poor results and have failed to confirm the results previously obtained.

The nitrate of soda had an excellent effect on the yield and apparently had some slight deterrent power.

Both applications of kainit gave an increase in yield over the check plot and exercised some deterrent effect over the white grubs. None of the fertilizers, however, can be considered as giving results of any very practical value in controlling the white grubs.

Mr. R. H. Van Zwaluwenburg, entomologist of the Federal Experiment Station, has recently carried out a series of four experiments with cyanamid and with eyanamid and acid phosphate, as agents for killing white grubs (Phyllophaga spp.) in cane lands. IIis results are appended herewith: 


\section{Summary of Results.}

HACIENDA SANTA RITA, GUANICA CENTRALE. APPLIED MARCH 13, 1917; COUNTS MADE APRIL 3, 1917.

\begin{tabular}{|c|c|c|}
\hline . & Number of stools & A verage grubs per stool \\
\hline 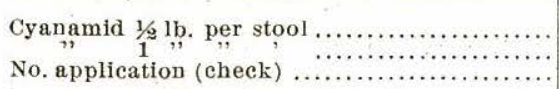 & $\begin{array}{r}299 \\
91 \\
115\end{array}$ & $\begin{array}{l}4.1 \\
3.6 \\
3.8\end{array}$ \\
\hline
\end{tabular}

HACIENDA PULIDO, CENTRAL ROCHELAISE, MAYAGUEZ, P. R., APPLIED OCTO. BER 8 TO SIX-MONTHS-PLANT OANE; COUNT'S MADE NOVEMBER 23, 1917.

\begin{tabular}{l|c|c}
\hline & Number of stools & Average grubs per stool \\
\hline Cyanamid and acid phosphate 1 lb. per stool... & 50 & 3.2 \\
Cyanamid and acid phosphate 2lbs. per stool... & 39 & 3.3 \\
No. application (check) ....................... & 59 \\
\hline
\end{tabular}

In this experiment there was so much variation in soil conditions, a ledge of tosca coming out near the surface over much of the field, that not much reliance can be placed on the figures obtained.

At Central Aguirre applications were made in the absence of sufficient grubs to obtain any reliable figures. In one field it was noted that first-instar grubs were present in treated stools, indicating that the eggs are not killed by applications of one pound of cyanamid per stool.

The applications made at Corsica Central were not disturbed. Applications of one pound of cyanamid and one pound of cyanamid and acid phosphate caused no injury at all to young ratoon cane.

Cyanamid alone and cyanamid mixed with an equal weight of acid phosphate are of no practical value against white grubs when applied in amounts up to two pounds to the stool, either when applied as a surface dressing or when worked into the top four inches of soil.

\section{Poison sprays.}

Numerous attempts have been made from time to time to kill the beetles by spraying their food plants with arsenical poisons. Since the beetles have biting mouthparts, are hearty feeders and do not fly far, but confine their feeding activities to the immediate vicinity of the cane fields, it seemed highly probable that such methods of control would meet with some success. The arsenicals used in these experiments were arsenate of lead and Paris green. Of the numerous experiments conducted the following four have been selected as being. indicative of the results obtained. 


\section{Experiment XVI.}

Five hundred beetles were eaught while feeding on the foliage of young cane. They were placed in a cage and fed for ten days on a common weed, "bleda," (Amaranthus spp., a favorite food plant of the beetles), the foliage of which had been sprayed with a solution of arsenate of lead three pounds to fifty gallons of water. At the end of this time the eage was examined and four hundred and sixty-eight of the beetles were found dead while the remaining thirty-two were very sluggish. An analysis of the dead beetles revealed traces of arsenic.

\section{Experiment XVII.}

A patch of "bleda" in the vicinity of some cane fields was sprayed with a solution of arsenate of lead of the same strength as that used in the previous experiment. At night five hundred and sixty-five beetles were caught feeding on this poisoned "bleda" and were immediately placed in a cage and fed on fresh, unsprayed material. At the end of a week one hundred and fifteen were found dead, and a week later two hundred more. Analysis showed traces of arsenic.

\section{Experiment XVIII.}

This experiment was a repetition of Experiment No. XVI, with the difference that a solution of Paris green was used to poison the "bleda" in place of the arsenate of lead. The solution was made up of one pound Paris green, one hundred and twenty-five gallons of water, twelve and one-half pounds of flour and two and one-half gallons of milk of lime. At the end of ten days an examination revealed two hundred and nineteen dead beetles, two hundred and eighty-one still being alive.

Favorite food plants of the beetles in the fields were sprayed with different strengths of arsenate of lead and Paris green. Beetles were collected at night feeding on these sprayed plants and were kept in cages without food to watch the effect of the poison on them.

Experiment XIX.-Experiment with Arsenate of Lead and Paris Green.

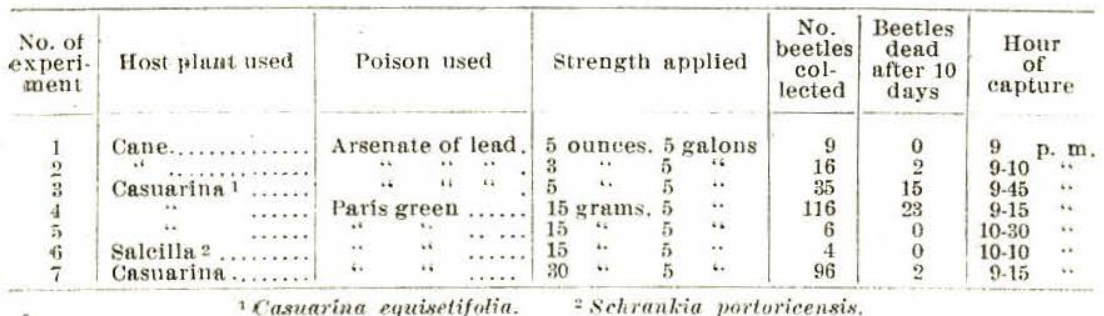


In this experiment the death rate of the beetles was not greater than would be normal with healthy beetles kept without food. It seems probable in this case that the beetles were captured before they had consumed any considerable quantity of the poisoned foliage.

As a result of these experiments it would appear that the spraying of the food plants of the beetles would undoubtedly cause the death of a portion of the beetles; that the working of the poison is slow and that the beetles would probably crawl to their burrows in the soil before dying; and that arsenate of lead is more effective as a poison for the beetles than Paris green. Unfortunately the practice of spraying large fields of cane and the trees in the vicinity of the fields is too expensive to be practical.

\section{MECHANICAL METHODS.}

Use of dynamite against the white grubs.

To test the value of dynamite as an agent with which to destrov the white grubs in infested land an experiment was carried out, in which various charges of dynamite were exploded at different depths in the soil and at distances of five feet apart. Previous to the blasting a careful estimate was made of the number of grubs present in the field. Three areas of eight square feet were selected in different parts of the field and a count made of all the grubs found within those areas. By this method it was estimated that there were one hundred and ninety-six thousand and twenty grubs per acre.

\section{Experiment XX.-Experiments with Dynamite Against the White Grub.}

\begin{tabular}{|c|c|c|c|c|c|c|c|}
\hline $\begin{array}{l}\text { Exp. } \\
\text { No. }\end{array}$ & $\begin{array}{l}\text { No. } \\
\text { of blasts } \\
\text { made }\end{array}$ & $\begin{array}{l}\text { Amount } \\
\text { dynamite } \\
\text { used per } \\
\text { charge }\end{array}$ & $\begin{array}{l}\text { Distance } \\
\text { between } \\
\text { charges }\end{array}$ & $\begin{array}{l}\text { Depth of } \\
\text { eharge } \\
\text { in soil }\end{array}$ & $\begin{array}{c}\text { Diameter of } \\
\text { hole made } \\
\text { by blast }\end{array}$ & $\begin{array}{c}\text { Soil left } \\
\text { untonched } \\
\text { by blast }\end{array}$ & $\begin{array}{c}\text { Per cent } \\
\text { grubs } \\
\text { killed }\end{array}$ \\
\hline $\begin{array}{l}1 \\
\frac{2}{3} \\
3\end{array}$ & $\begin{array}{l}6 \\
6 \\
4\end{array}$ & $\begin{array}{l}1 / 4 \\
1 / 4 \\
1 / . \\
1 / z\end{array}$ & $\begin{array}{c}5 \text { feet } \\
: . \\
\ddot{.} \\
. \cdot\end{array}$ & $\begin{array}{cc}8 & \text { inches } \\
16 & . \\
8 & . .\end{array}$ & $\begin{array}{l}2 \text { feel } \\
21 \%\end{array}$ & $\begin{array}{l}3 \text { feet } \\
21 / 2 "\end{array}$ & $\begin{array}{r}52 \\
52 \\
72\end{array}$ \\
\hline
\end{tabular}

As may be seen from the chart, best results were obtained by using a charge of one-half stick of dynamite. However, even that amount exploded at distances of five feet apart left one-half the surface of the ground undisturbed, and in the area that was thrown up by the explosion only seventy-two per cent of the grubs were killed. Many of the grubs were thrown out on the surface of the soil without injury. With charges at five feet apart it would have required one thousand seven hundred and forty-two charges per acre, which would have made the cost per acre, exclusive of fuses. caps, 
or labor, $\$ 239.46$. This, of course, made such a practice prohibitive, even had it been successful in destroying the grubs.

Flooding as a method of controlling the white grub.

In localities where there is an abundant supply of water, it was thought possible that by flooding the infested fields for a certain time that the white grubs might be destroyed. To test this theory the following experiments were made.

Several lots of white grubs were submerged in a tank of water for varying lengths of time. They were then taken out and examined.

Experiment XXI.-Effect of Flooding on White Grubs.

\begin{tabular}{c|c|c|c|c}
\hline $\begin{array}{c}\text { No. } \\
\text { of } \\
\text { Exp. }\end{array}$ & No. of grubs nsed & $\begin{array}{c}\text { No. of hours kept } \\
\text { under water }\end{array}$ & $\begin{array}{c}\text { Per cent } \\
\text { of grubs alive after } \\
\text { treatment }\end{array}$ & $\begin{array}{c}\text { Per cent } \\
\text { of grubs dead after } \\
\text { treatment }\end{array}$ \\
\hline 1 & 100 & 2 hours & 96 & 4 \\
2 & 100 & 4 & 100 & 0 \\
3 & 50 & 4 & 100 & 0 \\
4
\end{tabular}

In practically all cases the submergence had no other effect than to make the grubs rather sluggish and limp. They soon regained their normal active condition after being exposed to the air. A further experiment was conducted along these lines to determine whether or not a longer submergence would have different results. Several ditches were plugged at each end and filled with water. A large number of white grubs were then placed in the ditches and left for a period of two weeks. The water was then drawn off and the grubs found to be still alive and active. It would seem from the results of these experiments that flooding would be useless as a method of controlling the white grubs.

\section{Use of light to attract beetles.}

Knowing that the majority of insects are attracted to light, attempts were made to destroy the beetles by taking advantage of this natural phenomenon. Arc lights and five hundred candle power Pitner gasoline lamps were used in these experiments, and were run through the beetle season from March to November. The lights were erected over large basins filled with molasses and water, so that the beetles attracted to the lights would fall in and be drowned. In the following experiment two of the lights were erected in the midst of cane fields heavily infested with the white grub, while the third was erected on the roof of a two-story building in the vicinity. 
Experiment XXII.-Use of Light Against the Beetles.

\begin{tabular}{|c|c|c|c|c|c|}
\hline $\begin{array}{c}\text { No. } \\
\text { of } \\
\text { light }\end{array}$ & Where located & Kind of light & Time when run & $\begin{array}{c}\text { No. } \\
\text { of beetles } \\
\text { caught }\end{array}$ & $\begin{array}{l}\text { Average } \\
\text { No. } \\
\text { caught } \\
\text { per night }\end{array}$ \\
\hline $\begin{array}{l}1 \\
2 \\
3\end{array}$ & $\begin{array}{l}\text { In cane field..... } \\
\text { on roof of bidg. } \\
\text { near cane field }\end{array}$ & $\begin{array}{l}\text { Are light......... } \\
\text {, } \\
\text { g00 e. p. Pitner } \\
\text { gasoline lamp }\end{array}$ & $\begin{array}{l}\text { Nightly from April } 20 \text { to May } 31 . \\
\text { Run for } 23^{1} \text { evenings in July, } \\
\text { Aug., Oct, and November }\end{array}$ & $\begin{array}{r}250 \\
65 \\
24\end{array}$ & $\begin{array}{l}6 \\
1.5 \\
1\end{array}$ \\
\hline
\end{tabular}

${ }^{1}$ On only 7 nights were May beetles taken.

The results of these trials clearly show that little success can be expected with light as a means of attracting the beetles. Since these experiments were conducted it has been found that Phyllophaga beetles of the Island are ordinarily attracted to light only during their flight to their food plants in the early part of the evening. The flight only lasts about an hour, and once they have started feeding the beetles are no longer attracted by light. Hence it would be useless to run the lights for more than an hour each night.

\section{Collection of the grubs and beetles.}

The most successful method of controlling the white grub that has yet been found is that of collecting the grubs and beetles. The method is rather expensive but it is the only sure way of keeping the pest from increasing.

Some idea of the expense may be obtained from the following figures supplied by Guánica Central, where this method is practiced. During seven months in 1914, a total of $2,255,000$ beetles and 1,662,000 grubs were collected at a cost of $\$ 2,710.60$. The following year $2,468,000$ beetles and $2,425,000$ grubs were collected at a cost of $\$ 3,443.77$. More of the grubs and beetles are being collected each year by this central in an endeavor to reduce the numbers of this pest, but unfortunately the method is not very generally practiced by the cane growers of the Island, and in fact the majority of the growers use no method of control whatsoever.

Collections of the grubs should be made when the land is being plowed. Large numbers of the grubs are turned up at this time and should be collected by boys and women following the plows. Where turkeys, chickens, and hogs are available they should be turned into the fields at plowing time, as they will find and devour those grubs that the pickers fail to see;

The beetles feed at night on the foliage of the cane and the trees in the vicinity of the cane fields. They are rather sluggish in their 
movements and may be readily captured. Boys and men can gu around at night with bags and lanterns and collect the beetles in large numbers by shaking them from their food plants.

The beetles fly during the months of March to November, inclusive, but they are more abundant and hence more easily collected at certain times during this period. These periods of abundance vary somewhat with the locality and it is necessary to watch conditions carefully in order to take advantage of them.

\section{INSECT PARASITES AND FUNGUS DISEASES}

In view of the fact that the white grubs of Porto Rico suffer but little from the attacks of insect parasites, attempts were made to introduce some from other parts of the world. Reports on these efforts have been made in other publications of this station, so that no further mention will be made of this work here.

In addition to the introduction of insect parasites attempts were made to utilize a disease of the grubs and beetles known as the green muscardine fungus, Metarrhizium anisoplice. A report on this work has been made by Mr. John A Stevenson, pathologist of this Station, and may be found in this number of the Journal.

\section{CONCIUUSION.}

In eonclusion it may be stated that control of the white grub is still one of the largest entomological problems of the Island and that undoubtedly a vast amount of work still remains to be carried out. The collecting of the grubs and beetles is at present the only practical method of holding them in check, and it is far from being entirely satisfactory.

It seems likely that the most promising road to success in whitegrub control for Porto Rico will be in the introduction of predacious and parasitic enemies. 